\title{
SKAITMENINIO RELJEFO MODELIO KÜRIMO METODAI IR TIKSLUMO TYRIMAS, TAIKANT SKAITMENINĖS FOTOGRAMETRIJOS TECHNOLOGIJA
}

\author{
Birutė Ruzgienè \\ Geodezijos ir kadastro katedra, Vilniaus Gedimino technikos universitetas, \\ Sauletekio al. 11, LT-10223 Vilnius, Lietuva \\ Geodezijos katedra, Klaipédos valstybinè kolegija, \\ Bijūnu g. 10, LT-91223 Klaipèda, Lietuva \\ El.paštas Birute.Ruzgiene@vgtu.lt \\ Iteikta 201002 01; priimta 20100401
}

\begin{abstract}
Santrauka. Skaitmeninès fotogrametrijos metodai taikomi ortofotografiniams žemèlapiams sudaryti. Šiam tikslui aerofotonuotraukos orientuojamos, ir formuojamas skaitmeninis Žemés paviršiaus reljefo modelis (DEM), skaitmeniniu ortofotografiniu transformavimo būdu atliekamas aerofotonuotraukų geometrinis apdorojimas - pašalinami geometriniai iškraipymai, atsiradę dèl fotokameros posvyrio, dèl centrinès projekcijos ir reljefo įtakos. Ypač svarbu skaitmeninį Žemès paviršiaus reljefo modelị sukurti tokio tikslumuo, kad būtų užtikrinta gera geometrinė skaitmeninių fotografinių vaizdų transformavimo kokybè. Skaitmeninès fotogrametrijos procesai eksperimentiškai analizuoti Aerogeodezijos institute (Kaunas) aerofotonuotraukas apdorojus skaitmenine fotogrametrine darbo stotimi PHOTOMOD. Šia programine sistema generuotas reljefo modelis (DEM) bei ortofotografinè nuotrauka, atlikus aerofotografinių vaizdų vidinį, reliatyvụjị bei absoliutụjị orientavimą. Skaitmeninis reljefo modeliavimas atliktas sukuriant netaisyklingų trikampių tinklinius modelius - TIN (Triangulated Irregular Network), sudarytus iš nesutampančių trikampių. Taikyti šie paviršiaus interpoliavimo metodai: adaptyvusis (adaptive), glodusis (Inverse Distance Weighted $(I D W)$ ) ir reguliarusis (Radial Basis Functions $(R B F)$ ). Atlikta palyginamoji skaitmeninių reljefo modelių, taikant skirtingus reljefo interpoliavimo metodus, analizè. Rekomenduojama taikyti adaptyvujj reljefo interpoliavimo metodą. Skaitmeninè programinè įranga LISA (Berlynas, Vokietija) taikyta skaitmeninio vietovès reljefo modelio kokybei tirti ir tikslumui vertinti.
\end{abstract}

Reikšminiai žodžiai: skaitmeninè fotogrametrija, vaizdų apdorojimas, reljefo modeliavimas, ortofotografinis žemèlapis, stereoskopinis matavimas, DEM tikslumas.

\section{1. İvadas}

Nūdienos kartografavimo technologijose plačiai taikomi skaitmeninès fotogrametrijos metodai. Šiais metodais apdorojami visų rūšių fotografiniai vaizdai, gauti pasyviuoju fotografiniu ar aktyviuoju būdais, fotografuojant Žemès paviršių iš Žemès atmosferos ar iš kosmoso iš bet kurios fotografuoti naudojamos priemonès (orlaivių ar kosminių aparatų) bei fotografuojant objektus iš artimų nuotolių.

Naujieji skaitmeniniai metodai vis aktualesni kuriant kartografinę produkciją ir lemia kartografavimo proceso efektyvumą. Tai pažangūs kartografavimo būdai, kai matavimai skaitmeniniuose fotografiniuose vaizduose atliekami automatiškai ar pusiau automatiniu būdu.

Taikant skaitmeninès fotogrametrijos technologiją sukuriami skaitmeniniai Žemès paviršiaus aukščių modeliai, atliekami pavienių objektų stereoskopiniai matavimai bei generuojamos skaitmeninès ortofotografinès nuotraukos.
Skaitmeninėmis fotogrametrinėmis programinėmis sistemomis - fotogrametrinemis darbo stotimis (pvz., Delta, Geosystems, Ukraina; Image Station, Z/I Imaging, Vokietija/JAV; PHOTOMOD, Racurs, Maskva, Rusija) atliekamos fotogrametrinès procedūros, ir taip sukuriami trimačiai skaitmeniniai vietovès paviršiaus modeliai. Siekiant didžiausio geoduomenų generavimo iš aerofotonuotraukų produktyvumo ir efektyvumo, ištiriamas fotogrametrinių programinių sistemų funkcionalumas, galimybès, privalumai ir trūkumai bei parenkama optimali technologija (Ruzgienè, Aleknienè 2007; Ruzgienè 2007).

Skaitmeniniai ortofotografiniai žemèlapiai plačiai naudojami geoinformacinèse sistemose (Konecny 2003). Šiose sistemose informacija apie vietovès objektus pateikiama sluoksniais. Ortofotografiniai žemèlapiai yra vektorizuojami taikant standartizuotą objektų kodavimo sistemą GIS programinemis sistemomis, pvz., MicroStation, Autocad, Geomedia, Geomap, ArcView, ArcInfo, ArcGis ir kt. 
Siekiant sukurti kokybišką kartografinę produkciją bei gauti patikimus trimačių modelių generavimo rezultatus, analizuojami skaitmeninès fotogrametrijos procesai. Eksperimentinis tyrimas vyko Aerogeodezijos institute (Kaunas) aerofotonuotraukas apdorojant fotogrametrine darbo stotimi PHOTOMOD.

Žemès paviršiaus modelio empirinis tikslumas tirtas atliekant stereoskopinius matavimais fotografinių vaizdų apdorojimo sistema LISA (Berlynas, Vokietija) (Linder 2006) bei skaičiuojant fotografiniuose vaizduose parinktų pavienių ryškių taškų (objektų) aukščių paklaidas.

\section{Skaitmeninis fotogrametrinis aerofotonuotraukų apdorojimas}

Eksperimentinio aerofotonuotrauku apdorojimo programinè ịranga - skaitmeninè fotogrametrinè darbo stotis PHOTOMOD (Racurs, Maskva, Rusija). Ši programinė sistema plačiai taikoma gaminant fotogrametrinę kartografinę produkciją, yra funkcionali ir efektyvi (Photomod 2010). Fotogrametrinemms procedūroms atlikti naudojami skaitmeniniai fotografiniai vaizdai - skenuotos aerofotonuotraukos arba fotonuotraukos, gautos fotografuojant skaitmenine fotokamera.

I skaitmeninès fotogrametrinès stoties komplektą i̇eina specializuota 3D kompiuterinè pelè bei stereoskopinio vaizdo stebejjimo įranga.

Fotogrametrinès sistemos $P H O T O M O D$ pagrindinès funkcijos:

- stereoskopinių modelių sudarymas,

- planimetrinis objektų modeliavimas,

- aerotrianguliacijos uždavinių sprendimas - pusiau automatinis arba automatinis taškų koordinačių matavimas ir blokinis fotogrametrinio tinklo išlyginimas,

- skaitmeninių vietovès modelių kūrimas,

- ortofotografinių vaizdų generavimas,

- pavienių ortofotografinių nuotraukų jungimas,

- projektų jungimas.

Fotografinė medžiaga eksperimentiniams matavimams atlikti - Vilniaus miesto šiaurès rytų dalies analoginiai 1:6000 mastelio fotografiniai vaizdai. Vietovè fotografuota aerofotokamera RMK TOP. Aerofotokameros objektyvo židinio nuotolis $c=153,6 \mathrm{~mm}$. Aerofotografavimo skrydžio aukštis $H=100 \mathrm{~m}$. Išilginè aerofotonuotrauku sanklota - $62 \%$, skersinè - $33 \%$. Aerofotonuotraukų pozityvai nuskenuoti $14 \mu \mathrm{m}$ skiriamosios gebos fotogrametriniu skeneriu Vexell Ultra Scan ir pateikti TIF formatu.

Atramos, naudotos išoriniam aerofotonuotraukų orientavimui, taškų koordinatès nustatytos GPS $6 \mathrm{~cm}$ tikslumu.

Fotografiniams vaizdams skaitmeniniu fotogrametriniu būdu apdoroti sukurtas dviejų modelių vieno skrydžio maršruto fotogrametrinis blokas (C24_229, C25_228, C26_227) (1 pav.). Aerofotonuotraukos C26_227 skenavimo skiriamoji geba - $24 \mu \mathrm{m}$.

Skaitmenine fotogrametrine darbo stotimi PHOTO$M O D$ atlikus aerofotografinių vaizdų vidinị, reliatyvųji bei absoliutųji orientavimą, sukurtas skaitmeninis reljefo modelis (DEM) bei generuota ortofotografinè nuotrauka.

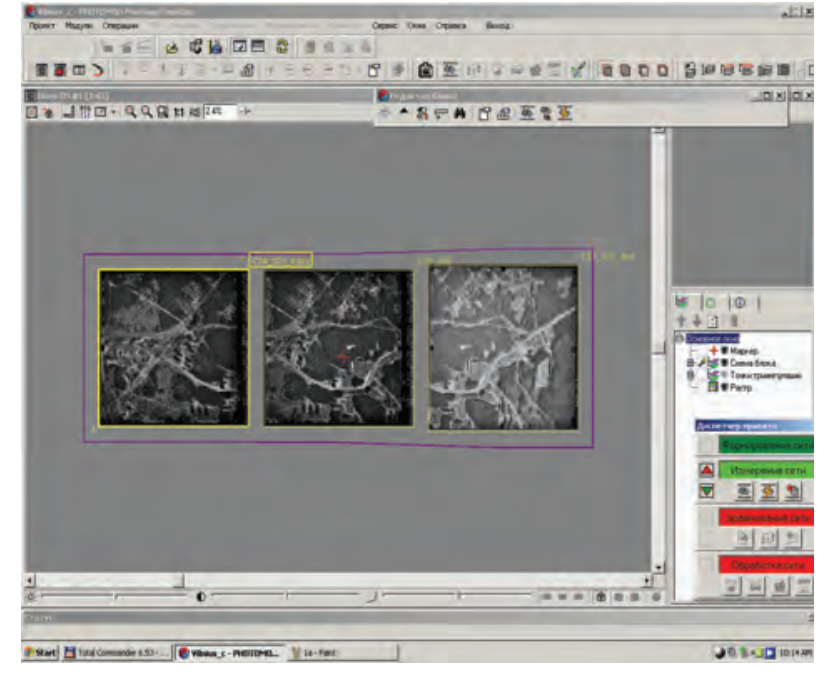

1 pav. Eksperimentinis fotogrametrinis blokas $P H O T O M O D$ programineje sistemoje

Fig. 1. Experimental photogrammetric block used in PHOTOMOD software

Fotogrametrinis skaitmeninis reljefo modeliavimas atliekamas automatiškai kuriant tankų planimetrinių koordinačių ir vietovès aukščių taškų tinklą. Šiam tikslui taikomi ịvairūs interpoliavimo metodai. Pradiniai duomenys - aerotrianguliacijos rezultatai. Taškų altitudès gali būti skaičiuojamos pagal formulę (Didactic 2005):

$$
Z=\sum\left(\frac{Z_{i}^{W_{i}}}{W_{i}}\right),
$$

čia $Z_{i}$ - atramos taškų altitudès taikomoje aukščių sistemoje; svorinis koeficientas $W_{i}=\frac{1}{d_{i}^{n}}, d$ - atstumas tarp interpoliuojamojo taško ir kiekvieno žinomo atramos taško, $n$ - laipsnis, kuriuo keliamas atstumas.

Generuojamo DEM tinklo tankumas priklauso nuo vietovės reljefo. Jei vietovės reljefas nėra labai raižytas, tai užtenka nustatyti taškų aukščius kas 5-10 m, tačiau kuo aukščių tinklas yra tankesnis, tuo interpoliavimo rezultatai patikimesni.

Eksperimentinès vietovès skaitmeninis reljefo modelis sukurtas formuojant netaisyklingus trikampius tinklus TIN (Triangulated Irregular Network), sudarytus iš sanklotos nesudarančių trikampių, apskaičiuotų pagal žinomų paviršiaus taškų padètis ir aukščius. TIN modelis formuojamas taikant Delauny trianguliacijos metodą. Trikampių linijos yra minimaliu atstumu viena kitos atžvilgiu, ir nè viena linija nesusikerta. Kiekviena trikampio kraštinè yra tolygaus nuolydžio. Tuo atveju, kai paviršiaus interpoliavimo algoritmai taikomi taisyklingam tinklui, TIN transformuojamas į taisyklingo DEM. Šiam tikslui atliekamas aukščių interpoliavimas tarp TIN viršūnių ir kiekvieno tinklo elemento centro. Taikomi ịvairūs interpoliavimo metodai: artimiausio kaimyno (Nearest Neighbor), mažiausiųjų kvadratų (Moving Least Square), svorinio atstumo (Inverse Distance Weighted (IDW)), apskritiminès funkcijos (Radial Basis Functions (RBF)), Krigingo (Kriging) (Wolf 2000; Manual ... 2004). 
Skaitmeniniam reljefo modeliui generuoti PHOTO$M O D$ programine sistema sukurti tinkliniai modeliai

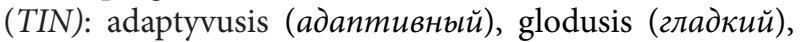
taisyklingasis (регулярньй) (2 pav.).

TIN formuojamas pagal vektorinius, plotinius duomenis bei pagal aukščių taškų rinkinius. Modelių patikimumas gerinamas brèžiant reljefo lūžio linijas ir įvedant $3 \mathrm{D}$ vektorinius duomenis.

Reguliarusis tinklinis modelis kuriamas taikant fotografinių vaizdų koreliacijos algoritmą - stereoporoje ieškoma geriausio atitikmens. Identifikuojami nusistatytojo stačiakampio tinklo mazginiai taškai ir apskaičiuojami jų aukščiai. Jei kurio nors mazginio taško aukčio automatiškai apskaičiuoti negalima (neatitinka vaizdų koreliacijos sąlygos), tai šių taškų aukščių reikšmès skaičiuojamos interpoliuojant tarp gretimų automatiškai surastųjų mazginių taškų. Sukurtasis tinklas koreguojamas rankiniu būdu. Tinklinis modelis (trikampių tinklas) formuojamas pagal reguliariojo tinklo mazginius taškus, taikant Delauny algoritmą. Reguliarujj TIN rekomenduojama taikyti, jei fotografiniai vaizdai yra heterogeniniai, t. y. ryškios, grūdètosios tekstūros, ir matoma pakankamai daug objektų detalių.
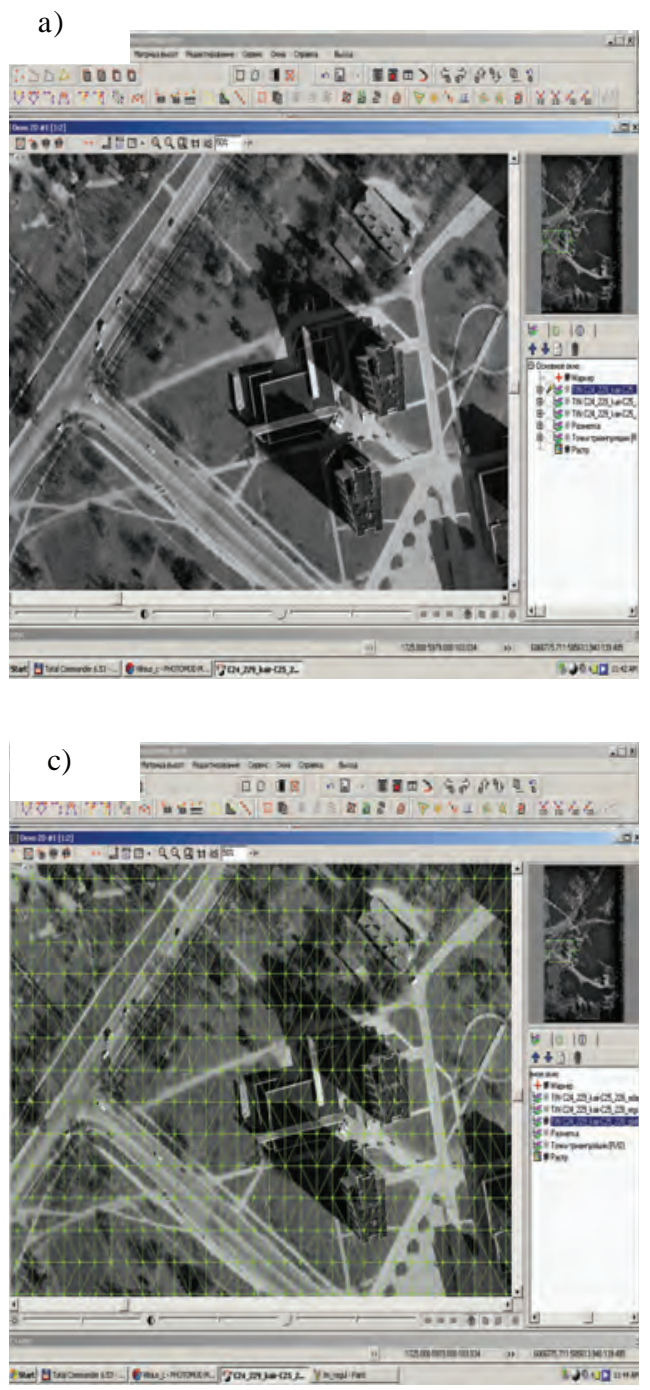

Adaptyvusis tinklinis modelis kuriamas fotografinių vaizdų sugretinimo (palyginimo) būdu. Identifikuojami geriausios koreliacijos taškai kiekvienoje skaitmeninio vaizdo ląsteleje, ir apskaičiuojami jų aukščiai. Jei surastojo taško koreliacijos koeficiento reikšmè mažesnè už ribinę (nusistatytąją), tai toks taškas automatiškai eliminuojamas. Gautieji taškai formuojami i netaisyklingų trikampių tinklą Delauny trianguliacijos principu. Adaptyvusis tinklinis modelis dažniausiai taikomas ir rekomenduojamas, kai vaizdai apima dideles homogenines bei lygaus paviršiaus teritorijas, bei kuriant vietovès paviršiaus $3 \mathrm{D}$ modelius artimų nuotolių fotogrametrijoje.

Glodusis tinklinis modelis sudaromas pagal 3D taškų rinkinị ir skiriamas polinominiam paviršiui generuoti. Apskaičiuojami trikampių tinklo žinomos padèties mazginių taškų aukščiai. Glodžiajame paviršiaus modelyje polinomine interpoliavimo funkcija sprendžiama pagal žinomus 3D taškus, reljefo lūžio linijų vektorinius duomenis bei trianguliacijos taškus. Glodusis tinklas taikomas, kai reljefas yra visiškai lygus, ir beveik nèra ryškių reljefo pokyčio taškų.
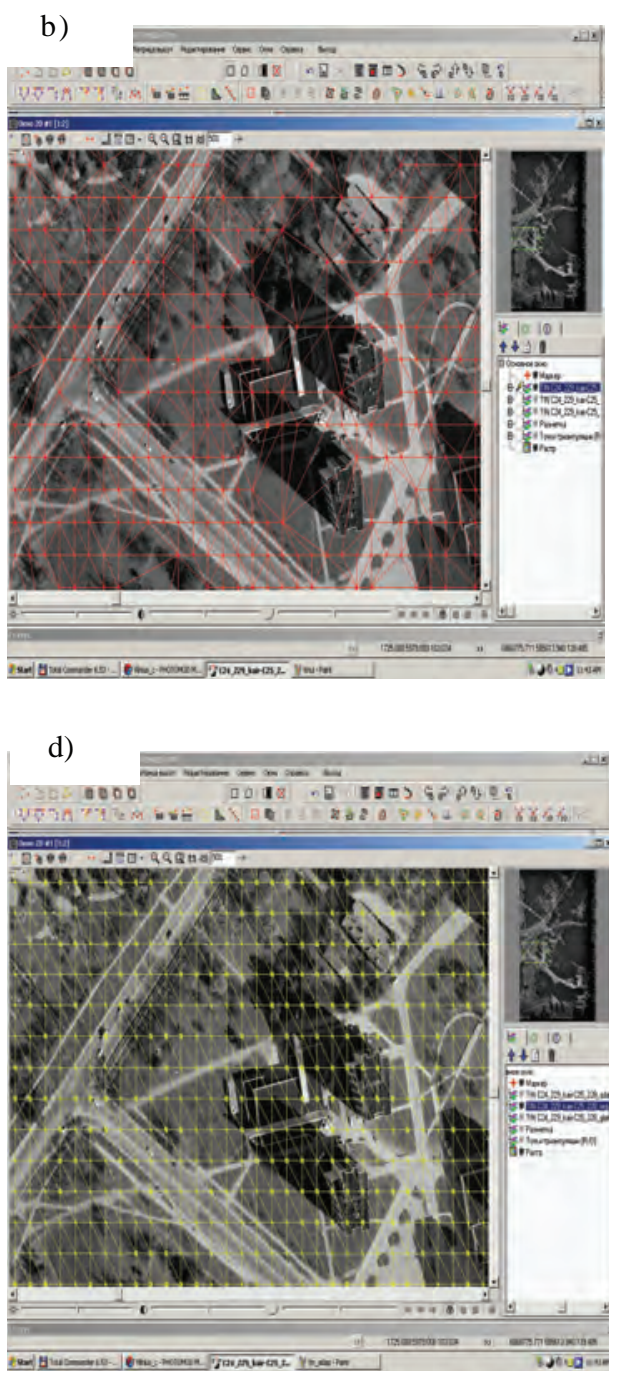

2 pav. Reljefo modeliavimas: a) fotogrametrinio modelio fragmentas, b) adaptyvusis TIN, c) glodusis, d) taisyklingasis

Fig. 2. Relief modeling: a) fragment of photogrammetric model, b) adaptive TIN, c) smooth, d) regular 
Automatiškai sukūrus reljefo modelį, DEM tikrinamas bei koreguojamas rankiniu būdu. Pvz., miškuose reljefas fiksuojamas medžių viršūnèmis. Šiuo atveju DEM tinklo viršūnių altitudès taisomos nuleidžiant taškus ant žemès paviršiaus. Dažnai redaguojamos upių ar ežerų krantų linijos. Kiekviename stereomodelyje tikrinami ir taisomi kelių, aukštų statinių ir kt. aukščiai. DEM kokybẻ ivertinama pagal žinomų atramos taškų koordinates.

Ortofotografinèje nuotraukoje (3 pav.) matomi ryškūs vietovès objektų iškraipymai, gauti dèl netinkamai sukurto (neredaguoto) reljefo modelio bei nevienodų pavienių modelių radiometrinių savybių.

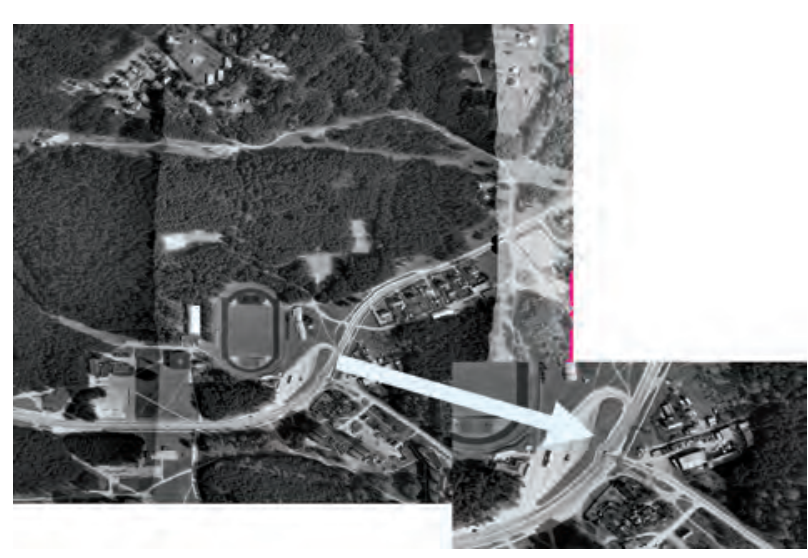

3 pav. Ortofotografinè nuotrauka su matomais radiometriniais ir objektų padèties iškraipymais

Fig. 3. Orthophoto with visible radiometric and objects position deformations

Skaitmeninis Žemès paviršiaus reljefo modelis kuriamas tokiu tikslumu, kad būtų užtikrinta gera geometrinè skaitmeninių fotografinių vaizdų transformavimo kokybè.

\section{Reljefo modelio kokybės kontrolè}

Skaitmenine fotogrametrine programine sistema LISA sukurto eksperimentinès vietovès reljefo modelio kokybei patikrinti atlikti stereoskopiniai matavimai bei empiriškai nustatytos reljefo modelio taškų aukščių paklaidos (Kraus 1997):

$$
d h=p_{x} \frac{h}{b}
$$

čia $h=Z_{01}-Z_{D E M}, h-$ taško reljefo modelyje aukštis, $b$ - fotografavimo bazè, $Z_{01}$ - kairiojo fotografinio vaizdo projekcijos centro altitude, $Z_{D E M}$ - taško reljefo modelyje altitude; $p_{x}$ - išilginis fotografinių vaizdų paralaksas.

Vietovès reljefo modelio, sukurto transformuojant fotografinius vaizdus, kokybei užtikrinti svarbu tinkamai parinkti DEM generavimo žingsnị. Išanalizuojami vietovès reljefo ypatumai. Kadangi eksperimentinès teritorijos reljefas nėra labai ryškus (vidutinis aukščių skirtumų svyravimas apie 5-8 m), tai parinktas reljefo modelio generavimo žingsnis $2 \mathrm{~m}$.
Vietovès skaitmeninio reljefo modelio generuojamo fotogrametriniu būdu tikslumas apskaičiuojamas pagal formulę (Ruzgienè 1999):

$$
m_{h}=H \frac{d_{x}}{r_{n}} \frac{1: m_{\text {aero }}}{1: m_{\text {orto }}},
$$

čia $d_{x}$ - leistinasis taškų poslinkis ortofotografineje nuotraukoje dèl reljefo ịtakos; $r_{n}$ - fotogrametrinių taškų atstumas nuo aerofotonuotraukos nadyro taško; $1: m_{\text {aero }}$, $1: m_{\text {orto }}$ - aerofotonuotraukos ir ortofotografinio žemèlapio masteliai, $H$ - aerofotografavimo aukštis.

Sukurtojo vietovès reljefo modelio tikslumas apskaičiuotas pagal (3) formulę:

$m_{h}=30 \mathrm{~cm}$, kai $r_{n}=10 \mathrm{~cm}, d_{x}=0,1 \mathrm{~mm}, H=$ $1000 \mathrm{~m}, 1: m_{\text {aero }}=1: 6000,1: m_{\text {orto }}=1: 2000$.

DEM kokybès kontrolè atliekama analizuojant vidinị bei išorinị tikslumą. Išorinis tikslumas - fotografinių vaizdų orientavimo paklaidos, nustatytos pagal 18 atramos (aerotrianguliacijos) taškų altitudes. Atlikus išorinị fotografinių vaizdų orientavimą gautas tikslumo ịvertis $0,007 \mathrm{~m}$, o didžiausia išorinio orientavimo paklaida 0,017 m (4 pav.).

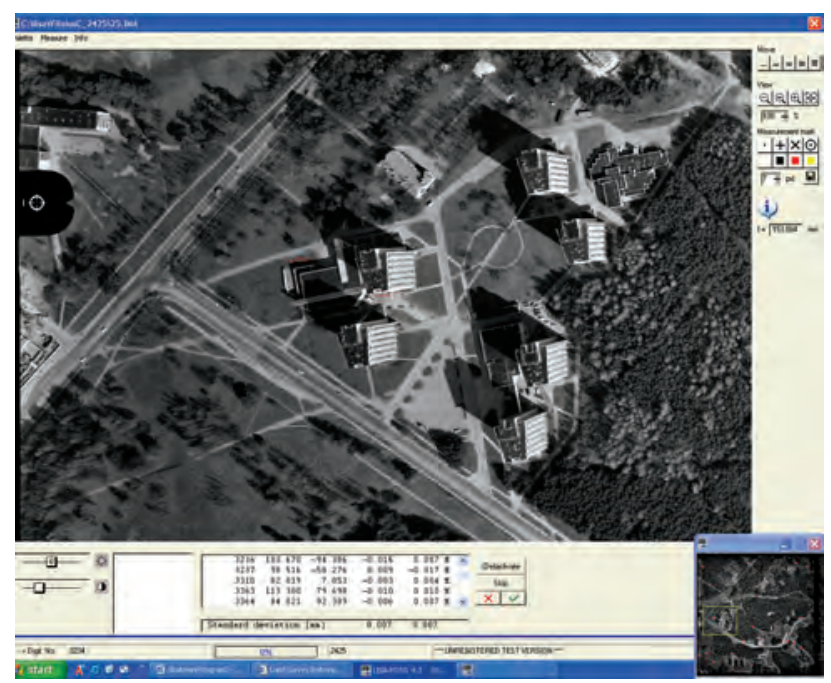

4 pav. Išorinio fotografinių vaizdų orientavimo rezultatų fragmentas

Fig. 4. Fragment from images inner orientation results

Vietovès reljefo modelio vidinis tikslumas analizuotas stereoskopiniame modelyje (5 pav.). Stereoskopiškai matuoti pasirinktieji DEM tinklo taškai. Stebèta matavimo žymès padètis kairiajame ir dešiniajame vaizduose ir stereoskopiškai matuoti taškų aukščiai. Taikytas anaglifinis stereoskopinio matymo būdas.

Fotografiniuose vaizduose stereoskopiškai išmatuoti visame stereoskopinio modelio plote parinkti reljefo modelio vietovès taškai - apie $15 \%$ visų koreliuotųjų tinklo taškų. Nematuoti taškai miškų plotuose, ant ịvairių statinių stogų, ant aukštuminių pastatų. Atlikus vizualinę pavienių taškų identifikavimo kontrolę, apie 1\% klaidingų automatiškai identifikuotų taškų eliminuota. 


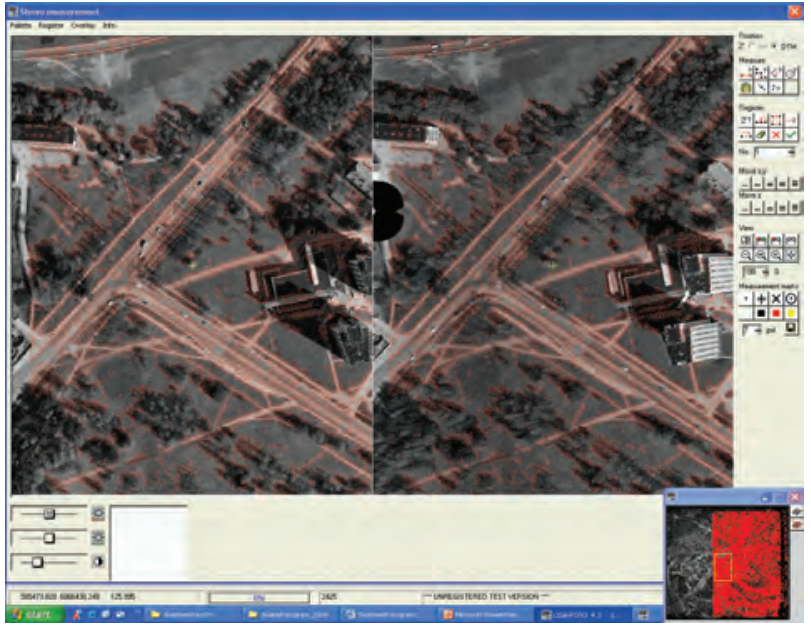

5 pav. Reljefo modelio fragmentas stereoskopinio matavimo funkcijoje. Koreliuotụjų taškų skaičius - 233610

Fig. 5. Fragment of relief model in stereoscopic measurement mode. Number of correlated points - 233610

Nustatyta, kad daugelio reljefo modelio taškų homologinès padètys tikslios. Tik apie $5 \%$ stereoskopiškai išmatuotų taškų aukščių nuokrypis - 0,5 pikselio dydžio, t. y. $4,2 \mathrm{~cm}$.

Kai kurie statistiniai fotografinių vaizdų koreliacijos skaičiavimų duomenys pateikti 1 lentelèje. Minimali koreliacijos koeficiento reikšmè - 0,66 , vidutinė - 0,80 , o tikslumo ịvertis - 8,942 mm. Reljefo modelyje daugiausiai padėčių rasta, kai koreliacijos koeficiento reikšmė yra 0,75. Apie $14 \%$ padèčių koreliacija 0,90. Labai geri fotografinių vaizdų sutapatinimo rezultatai gaunami, kai koreliacijos koeficiento reikšmès 0,90-0,95.

1 lentelè. Kai kurie statistiniai fotografinių vaizdų palyginimo duomenys

Table 1. Some statistics data derived via images matching

\begin{tabular}{|c|c|c|c|c|}
\hline \multicolumn{4}{|c|}{ M inimali koreliacijos koeficiento vertè $(\%)>$} & 66 \\
\hline \multicolumn{4}{|c|}{ V idutine $>0$} & 79,962 \\
\hline \multicolumn{4}{|c|}{ Standartinis nuokrypis $>0$} & 8,942 \\
\hline \multicolumn{4}{|c|}{ Pikseliu skaičius } & 1276479 \\
\hline \multicolumn{4}{|c|}{ V aizdo formatas [bit] } & 8 \\
\hline & Plotas $[\mathrm{m}]$ & {$[\%]$} & $\mathrm{S}[\%] *=$ & $=2 \%$ \\
\hline$<70$ & 38902,000 & 17,193 & 17,193 & $* * * * * * * *$ \\
\hline$<75$ & 47738,000 & 21,098 & 38,291 & $* * * * * * * * * *$ \\
\hline$<80$ & 37152,000 & 16,419 & 54,710 & $* * * * * * * *$ \\
\hline$<85$ & 33152,000 & 14,652 & $69,361 \times$ & $* * * * * * *$ \\
\hline$<90$ & 32454,000 & 14,343 & 83,704 & $* * * * * * *$ \\
\hline$<95$ & 28671,000 & 12,671 & 96,376 & $* * * * * *$ \\
\hline
\end{tabular}

Be to, vietovès reljefo modelio tikslumui tirti taikytas empirinis būdas. Visame fotografinių vaizdų stereoskopiniame modelyje parinkti 35 būdingieji, ryškių kontūrų, reljefo taškai ir pagal (2) formulę apskaičiuotos šių taškų aukščių paklaidos. Gautosios $d h$ reikšmès neviršijo $0,25 \mathrm{~m}$, o tikslumo įvertis $-0,16 \mathrm{~m}$.

\section{Išvados}

Siekiant gauti kuo tikslesnị Žemès paviršiaus modelị ortofotografinei nuotraukai generuoti, reikia taikyti tinkamą reljefo interpoliavimo algoritmą. Šiam tikslui analizuojami konkrečios vietovès reljefo ypatumai. Jei reljefas nèra labai raižytas, geriausias rezultatas gaunamas, kai reljefas modeliuojamas kuo tankesnio adaptyviojo interpoliavimo būdu sukurtame TIN.

Atlikus pagal 1:6000 mastelio aerofotonuotraukos medžiagą sukurtojo vietovès reljefo modelio kokybès analizę nustatyta, kad stereoskopiškai išmatavus gautas aukščių tikslumas neviršija reikalaujamo tiriamosios medžiagos tikslumo $-0,30 \mathrm{~cm}$. Grubios fotografinių vaizdų koreliacijos klaidos eliminuotos.

Tikslumo parametrai patikrinti taikant empirinị būdą ir nustatyta, kad pavienių paviršiaus taškų aukščių tikslumo įvertis atitinka kuriant toki modelị keliamus tikslumo reikalavimus.

Gautieji duomenys tinkami Žemės paviršiaus reljefo 3D modeliams sukurti ir tenkina stambiojo mastelio topografijos bei GIS poreikius.

\section{Literatūra}

Donnay J. P.; Kaczynski, R. 2005. Didactic and Digital Photogrammetric Software (DDPS). User's Guide. Department of Geomatics, University of Liege, Belgium, Institute of Geodesy and Cartography (IGiK), Department of Photogrammetry, Warszawa, Poland. $71 \mathrm{p}$.

Konecny, G. 2003. Geoinformation: Remote Sensing, Photogrammetry and Geographical Information Systems. London and New York: Taylor and Francis. 248 p. doi:10.4324/9780203469644

Kraus, K. 1997. Photogrammetry 2. Advanced Methods and Applications. Bonn: Dümmler. $466 \mathrm{p}$.

Linder, W. 2006. Digital Photogrammetry. A Practical Course. Springer-Verlag, Berlin, Heidelberg. 214 p.

Manual of Photogrammetry (Edited by Chris McGlone). 2004. Fifth Edition. American Society for Photogrammetry and Remote Sensing, Maryland, USA. 1151 p.

Photomod DTM [online], [cited 26 January 2010]. Available from Internet: < http://www.racurs.ru/?page=197> .

Ruzgienè, B.; Alekniené, E. 2007. Analytical and digital photogrammetric geodata production systems (a comparison test), Geodezija ir kartografija [Geodesy and Cartography] 33(2): 50-54.

Ruzgienè, B. 2007. Comparison between digital photogrammetric systems, Geodezija ir kartografija [Geodesy and Cartography] 33(3): 75-79.

Ruzgienè, B. 1999. Skaitmeninių ortofotografinių žemèlapių sudarymo tikslumas, Geodezija ir kartografija [Geodesy and Cartography] 25(3): 118-122.

Wolf, P. R; Dewitt, B. A. 2000. Elements of Photogrammetry: With Application in GIS. 3rd edition. McGraw-Hill. 608 p. 
Birutė RUZGIENĖ. Associate Professor, Doctor. Vilnius Gediminas Technical University, Dept of Geodesy and Cadastre, Saulètekio al. 11, LT-10223 Vilnius, Lithuania (Ph +370 52744 703, Fax +370 52744 705), e-mail: birute.ruzgiene@ap.vtu.lt.

A graduate of Vilnius Civil Engineering Institute (engineer of geodesy, 1968). Doctor (Vilnius Gediminas Technical University, 1999). Research training at Moscow Institute of
Geodesy, Aerosurveying and Cartography (1986), at Norway AO Fjellanger Widerøe (1995), at Warsaw Institute of Geodesy and Cartography (1998), at Photogrammetry Institute of Bonn University $(2000,2005)$. Author of more than 30 scientific papers.

Research interests: digital photogrammetric mapping, image interpretation, features extraction from remote sensing data. 